\title{
REAÇÃO ADVERSA NO TRATAMENTO DA TALASSEMIA MAJOR. Pôster
}

Autores deste trabalho:

Roberto Kenji Nakamura Cuman: Universidade Estadual de Maringá

Ricardo Alexandre Spironello: Universidade Estadual de Maringá

Área do Trabalho: Enfermagem pediátrica

Data da submissão:21/06/2018 às 11:43

\section{Justificativa}

Encontramos dois tipos de talassemia, a ( Alfa e Beta) e ela pode ser encontrada nas formas de:minor, intermediaria e major. Quando apresentada na forma minor produz um grau de anemia leve, na forma intermediaria existe uma deficiência de síntese de hemoglobina moderada menos grave. Na talassemia Major é uma forma grave da doença, por ter dois genes defeituosos um da mãe e um do pai, provocando anemia profundo entre outros sintomas graves. Seu tratamento é por terapia de quelação de ferro, com deferoxamina,contínuas transfusões e conseqüentemente acúmulo de ferro nos tecidos

\section{Objetivo(s)}

Este trabalho tem como finalidade relatar reações adversas de três pacientes infantis durante terapia de tratamento da Talassemia Major

\section{Método(s)}

As informações foram coletadas por meio de prontuário médico, com consentimento dos responsáveis pelo paciente.

\section{Resultado(s)}

Relato: Três pacientes com idade de 6,5 e 7 anos duas do sexo feminino e um do sexo masculino. Após a transfusão tiveram reção adversa e proteína plasmática, apresentando os sintomas ( reação alérgica,urticária e prurido).Rapidamente foram medicados, eliminando qualquer reação alérgica a proteína plasmática, realizado ( cloridrato de difenidramanina,anti-histaminico e hidrocortisona). Se voltasse acontecer a reação adversa,foi sugerido concentração de hemácias lavadas ou medicações anti- histaminicos.

\section{Conclusão (ões)}

O dados obtidos serão utilizados para a melhoria do serviço do hospital, no tratamento de pacientes com talassemia major, envolvendo uma melhor eficácia de drogas e também evitará as reações adversas a medicamentos. 